\title{
PENGARUH PAPER QUILLING TERHADAP KEMAMPUAN MOTORIK HALUS ANAK USIA 5-6 TAHUN DI TAMAN KANAK- KANAK
}

\author{
Arina Puspitasari ${ }^{凶}$ \\ Pendidikan Guru Pendidikan Anak Usia Dini, Universitas Negeri Makassar
}

\begin{abstract}
:
The purpose of this study was to determine the effect of paper quilling on the fine motor skills of children aged 5-6 years. This research approach is quantitative with the type of preexperimental research and the research design of one group pretest-posttest design. This study took place at ABA II Kindergarten, Arallae, Bone Regency, with the subject of research on the effect of paper quilling activities on fine motor skills consisting of 12 children as research samples. Data collection techniques used are observation, treatment test and documentation. The results of the analysis showed that there were significant changes in the fine motor skills of children before and after being given paper quilling activities, based on the paired sample test, the Sig value was obtained. (2-tailed) $0.000<0.05$, it can be concluded that there is an influence given by paper quilling activities on the fine motor skills of children aged 5-6 years. For further researchers in examining aspects of child development, it can be simulated with paper quilling activities.
\end{abstract}

Keywords: Paper quilling, Fine motor skills

\begin{abstract}
Abstrak:
Tujuan penelitian ini untuk mengetahui pengaruh paper quilling terhadap kemampuan motorik halus anak usia 5-6 tahun. Pendekatan penelitian ini adalah kuantitatif dengan jenis penelitian pre-eksperimen dan dengan desain penelitian one group pretest-posttest design. Penelitian ini bertempat di TK ABA II Arallae Kabupaten Bone dengan subjek penelitian pengaruh kegiatan paper quilling terhadap kemampuan motorik halus yang terdiri dari 12 anak sebagai sampel penelitian. Teknik pengumpulan data yang digunakan yaitu observasi, tes perlakuan dan dokumentasi. Hasil analisis diperoleh data bahwa terdapat perubahan yang signifikan pada kemampuan motorik halus anak sebelum dan sesudah diberikan kegiatan paper quilling, berdasarkan uji paired sampel tes diperoleh nilai Sig. (2-tailed) $0,000<0,05$ maka dapat disimpulkan terdapat pengaruh yang diberikan kegiatan paper quilling terhadap kemampuan motorik halus anak usia 5-6 tahun. Bagi peneliti selanjutnya dalam meneliti aspek perkembangan anak dapat disimulasi dengan kegiatan paper quilling.
\end{abstract}

Kata Kunci: Paper quilling; Kemampuan motorik halus 


\section{PENDAHULUAN}

Anak usia dini merupakan masa emas atau golden age yang sangat berharga bagi anak dimana tahap perkembangan anak dari usia 0-8 tahun berkembang dengan sangat cepat, anak akan mudah menyerap segala informasi yang diberikan. Masa perkembangan setiap anak sangat berbeda karena setiap anak memiliki keunikan dan bakat masing-masing (Damayanti, 2015). Suyanto dalam Kamelia (2019) menjelaskan bahwa pada masa ini pertumbuhan otak sedang mengalami perkembangan yang sangat pesat. Berdasarkan penelitian tentang otak, tingkat kapabilitas kecerdasan anak sampai 4 tahun telah mencapai $50 \%$, pada usia 8 tahun mencapai $80 \%$ dan sisanya sekitar $20 \%$ pada saat berusia 8 tahun keatas. Anak sebagai generasi penerus bangsa yang juga memiliki hak atas pendidikan, maka pendidikan anak usia dini saat ini sangat penting diperhatikan karena dengan memberikan pendidikan yang baik pada anak sejak usia dini akan mempengaruhi semua aspek perkembangannya (Huliyah, 2016).

Pendidikan menjadi langkah utama dalam tujuan untuk mencerdaskan bangsa, membentuk karakter anak dan membentuk kedisiplinan. Dalam hal ini pembelajarakan yang diajarkan untuk anak harus memenuhi kriteria aktif, kreatif, efektif dan menyenangkan (Rahmawati, dkk., 2019). Dalam mendukung proses pembelajaran pada anak guru PAUD perlu menuangkan semua ide-ide imajinasinya ke dalam media pembelajaran anak, karena media pembelajaran dapat membantu guru dalam menyampaikan materi pembelajaran pada anak. Asmariani (2016: 26) mengatakan bahwa media memegang peranan penting dalam proses pembelajaran anak usia dini. Media dapat dijadikan sebagai wahana untuk mendekatkan persepsi dan pemahaman guru dengan daya tangkap anak.

Dengan menggunakan media pembelajaran dapat meningkatkan mutu dan kualitas pembelajaran, karena media memiliki fungsi untuk menjelaskan informasi/pesan yang disampaikan oleh pengirim pesan kepada si penerima pesan, dalam hal ini guru adalah sebagai pengirim pesan dan anak sebagai penerima pesan (Asmariani, 2016). Salah satu media pembelajaran yang dapat diterapkan guru dalam pembelajarannya anak adalah kegiatan paper quilling. Paper quilling berupa kerajinan berbahan kertas yang melibatkan penggunaan potongan kertas yang digulung, dibentuk dan direkatkan untuk membuat desain dekoratif yang memperlihatkan nilai-nilai estetika sehingga menghasilkan karya seni yang indah dan menawan (Bartkowski \& Allison, 2011, Suskin, 2011 dan Artha, dkk., 2020).

Paper quilling adalah sebuah teknik menggulung kertas untuk menyusun kertas menjadi menjadi suatu karya seni. Mendesain gambar dengan cara kertas digulung menggunakan jari atau alat quilling sampai membentuk sebuah gulungan dengan ujung kertas yang direkatkan terlebih dahulu (Rahmawati, dkk., 2019). Sedangkan menurut Wisnu dalam Wahyuningtyas, dkk (2020) mengatakan bahwa paper quilling merupakan suatu kegiatan seni dalam keterampilan menggulung kertas yang memerlukan koordinasi otot halus pada jari-jari tangan. Semua proses yang dilalui anak dalam kegiatan paper quilling untuk membuat suatu karya yang berperan penting dalam memberi banyak manfaat bagi anak. Rohmatin \& Hasibuan (2017) mengatakan bahwa melalui kegiatan paper quilling dapat melatih kemampuan motorik halus pada anak. Anak berlatih menggunakan 
tangannya untuk menggulung kertas dan menempel dengan rapi. Dengan kegiatan paper quilling dapat membantu anak dalam mengembangkan kemampuan motorik halusnya. Namun dalam penelitian ini peneliti tidak hanya menggunakan kegiatan paper quilling untuk melatih kemampuan motorik halus anak dalam menggulung kertas dan dan menempel kertas dengan rapi tetapi juga melatih kemampuan motorik halus anak dalam menjepit kertas.

Kemampuan motorik halus sebagai salah satu dari enam aspek perkembangan yang perlu dikembangkan. Kemampuan motorik halus merupakan kemampuan yang memerlukan kekuatan otot-otot kecil untuk mencapai pelaksanaan keterampilan yang berhasil serta gerakan otot kecil yang membutuhkan koordinasi mata dan tangan (Wisudayanti, 2017; Martzog \& Sebastian, 2019). Kegiatan yang sesuai untuk meningkatkan kemampuan motorik halus seperti, meremas, membentuk, menyusun menara, meronce dan lainlain (Hera \& Latief, 2020: 101). Sujiono dalam Wahyuningtyas, dkk., (2020) menyatakan bahwa aktivitas motorik halus berupa gerakan yang dilakukan oleh otot halus yang akan mempengaruhi seberapa besar kesempatan yang diberikan untuk melatih dan belajar menggunting, menyusun beragam benda, menempel, mecoret, dan menggunakan alat tulis.

Kemampuan motorik halus sangat penting untuk dikembangkan karena memiliki peran penting dalam banyak aktivitas kehidupan sehari-hari sperti merawat diri, makan dan berpakaian (Gaul \& Johann, 2016). Beberapa informasi mengatakan bahwa banya guru yang mengeluh karena masih banyak siswanya yang memilki kemampuan fisik motorik yang kurang. Dari hal tersebut dapat diketahui bahwa kerja sama anatara orangtua dan guru sangat penting untuk membantu perkembangan anak terutama perkembangan kemampuan motorik halus anak (Suggate \& Eva, 2016).

Kemampuan motorik halus adalah suatu gerakan yang hanya melibatkan bagian tubuh tertentu dan dilakukan oleh otot-otot kecil yang memerlukan koordinasi yang cermat. Kemampuan motorik halus anak dapat dilatih dengan beberapa kegiatan seperti kegiatan menggunting, kegiatan menempel, kegiatan mewarnai, kegiatan menulis, merobek kertas menjadi bagian yang lebih kecil, kegiatan meremas-remas busa dan lain sebagainya (Ahmad, 2011). Adapun pengertian kemampuan motorik halus menurut Nursalam dalam Suhartani, dkk (2019) mengatakan bahwa kemampuan motorik halus adalah kemampuan anak dalam mengamati sesuatu dengan gerakan yang melibatkan otot-otot kecil serta koordinasi yang cermat dan tidak membutuhkan banyak tenaga.

Taman Kanak-Kanak ABA II Arallae merupakan salah satu sekolah yang beralamatkan di Desa Arallae, Kecamatan Kahu, Kabupaten Bone. Dari observasi yang telah dilakukan terdapat beberapa anak yang kemampuan motorik halusnya masih kurang dibandingkan dengan anak-anak yang lainnya. Hal ini terlihat pada aktivitas yang dilakukan anak di sekolah, seperti pada kegiatan mewarnai masih ada beberapa anak yang mewarnai dengan keluar garis dari gambar dan pada kegiatan menulis huruf, masih ada beberapa anak yang tidak dapat mengontol jari- jemarinya dengan baik sehingga tulisan anak menjadi miring.

Penyebab dari kurangnya kemampuan motorik halus anak usia 5-6 tahun Taman Kanak-Kanak ABA II Arallae juga karena fasilitas sekolah yang masih belum memadai terutama media pembelajaran, media pembelajaran yang digunakan terlalu monoton sehingga anak menjadi bosan dan tidak semangat dalam belajar yang dapat membantu 
kemampuan motorik halus pada anak. Untuk membantu pembelajaran anak dalam mengembangkan kemampuan motorik halus anak dapat dilakukan dengan bantuan media pembelajaran. Media pembelajaran dapat menjadi sumber pembelajaran bagi anak yang dapat membantu mengembangkan kemampuan motorik halus. Media paper quilling dapat diberikan pada kegiatan anak untuk membantu anak mengembangkan kemampuan motorik halusnya.

\section{METODE PENELITIAN}

Jenis penelitian ini adalah kuantitatif yaitu pre-ekperimen dengan desain penelitian one group pretest posttest design. Desain penelitian ini merupakan desain penelitian yang hanya menggunakan satu kelompok subjek saja, dan tidak ada usaha untuk mengendalikan variabel non-eksperimental. Pengukuran atau observasi dilakukann sebelum dan sesudah perlakuan, dan perbedaan hasil pengukuran tersebut dianggap sebagai efek dari perlakuan. Teknik pengambilan sampel dilakukan dengan teknik purposive sampling (pengambilan sampel berdasarkan pertimbangan) dengan sampel sebanyak 12 anak yang akan diberikan tes awal berupa tes perlakuan yaitu dengan menugaskan atau meminta anak mempraktekkan secara langsung menjepit, menggulung dan menempel kertas untuk mengetahui kemampuan motorik halus awal anak, setelah itu diberikan perlakuan berupa kegiatan paper quilling. Selanjutnya anak akan diberikan tes akhir berupa tes perlakuan yang sama seperti tes awal yaitu dengan menugaskan atau meminta anak mempraktekkan secara langsung menjepit, menggulung dan menempel kertas untuk mengetahui perkembangan kemampuan motorik halus anak setelah diberi perlakukan berupa kegiatan paper quilling. Penelitian ini dilakukan pada Anak usia 5-6 tahun yang berjumlah 12 anak di kelompok B Taman Kanak-Kanak ABA II Arallae Kabupaten Bone. Teknik pengumpulan data yang digunakan dalam penelitian ini adalah observasi, tes perlakuan dan dokumentasi. Apadapun teknik analisis data yang digunakan adalah statistik deskriptif, uji normalitas kolmogorov smirnov, dan analisis parametrik yaitu uji paired sample t-test menggunakan aplikasi SPSS. Teknik analisis data ini digunakan untuk mengetahui kemampuan motorik halus anak sebelum dan sesudah diberikan treatment kegiatan paper quilling, untuk mengetahui data yang diambil berdistribusi normal atau tidak, dan mengetahui pengaruh dari paper quilling terhadap kemampuan motorik halus anak usia 56 tahun di Taman Kanak-Kanak ABA II Arallae Kabupaten Bone.

\section{HASIL DAN PEMBAHASAN}

Data yang diperoleh dari penelitian ini merupakan hasil nilai anak yang diperoleh dari hasil tes perlakuan yaitu sebelum (pre-test) diberikan kegiatan paper quilling dan setelah (post-test) diberikan kegiatan paper quilling. Data pre-test dilakukan untuk mengetahui kemampuan motorik halus anak sebelum diberikan treatment kegiatan paper quilling. Sedangkan data post-test dilakukan untuk mengetahui kemampuan motorik halus anak sesudah diberikan kegiatan paper quilling. Berikut ini akan diuraikan data hasil penelitian tentang kemampuan motorik halus anak sebelum dan sesudah diberikan kegiatan paper quilling, hasil penelitian disajikan sebagai berikut. Distribusi pengkategorian kemampuan motorik halus anak sebelum (pre-test) diberikan kegiatan paper quilling. 
Tabel 4.1 Kategori Kemampuan Motorik Halus Anak (Pre-test)

\begin{tabular}{ccclc}
\hline No & Interval & Frekuensi & \multicolumn{1}{c}{ Kategori } & Presentase \\
\hline 1 & $16-17$ & 3 & Belum Berkembang (BB) & $25 \%$ \\
\hline 2 & $18-19$ & 4 & Mulai Berkembang (MB) & $33,3 \%$ \\
\hline 3 & $20-21$ & 4 & Berkembang Sesuai Harapan (BSH) & $33,4 \%$ \\
\hline 4 & $22-23$ & 1 & Berkembang Sangat Baik (BSB) & $8,3 \%$ \\
\hline \multicolumn{2}{l}{ Jumlah } & 12 & & - \\
\hline
\end{tabular}

Berdasarkan tabel diatas dapat diketahui bahwa dari 12 jumlah anak terdapat 3 anak dengan presentase $25 \%$ yang belum mampu dalam menggunakan tangan kanak dan kiri dalam menjepit kertas, belum mampu dalam menggunakan tangan kanan dan kiri dalam menggulung kertas, belum mampu melakukan gerakan terkoordinasi dalam membuat bentuk gulungan kertas dengan lincah, belum mampu mengekspresikan diri melalui gerakan menggulung kertas secara detail, belum mampu dalam menempel gulungan kertas sesuai pola dan belum mampu dalam menempel gulungan kertas dengan rapi dan sesuai pola sehingga termasuk pada kategori Belum Berkembang (BB). Terdapat 4 anak dengan presentase 33,3\% yang mampu dalam menggunakan tangan kanak dan kiri dalam menjepit kertas, yang mampu dalam menggunakan tangan kanan dan kiri dalam menggulung kertas, yang mampu melakukan gerakan terkoordinasi dalam membuat bentuk gulungan kertas dengan lincah, yang mampu mengekspresikan diri melalui gerakan menggulung kertas secara detail, yang mampu dalam menempel gulungan kertas sesuai pola dan yang mampu dalam menempel gulungan kertas dengan rapi dan sesuai pola sehingga termasuk pada kategori Mulai Berkembang (MB).

Terdapat 4 anak dengan presentase 33,4\% yang mampu dalam menggunakan tangan kanak dan kiri dalam menjepit kertas, yang mampu dalam menggunakan tangan kanan dan kiri dalam menggulung kertas, yang mampu melakukan gerakan terkoordinasi dalam membuat bentuk gulungan kertas dengan lincah, yang mampu mengekspresikan diri melalui gerakan menggulung kertas secara detail, yang mampu dalam menempel gulungan kertas sesuai pola dan yang mampu dalam menempel gulungan kertas dengan rapi dan sesuai pola sehingga termasuk pada kategori Berkembang Sesuai Harapan (BSH). Terdapat 1 anak dengan presentase $8,3 \%$ yang mampu dalam menggunakan tangan kanak dan kiri dalam menjepit kertas, yang mampu dalam menggunakan tangan kanan dan kiri dalam menggulung kertas, yang mampu melakukan gerakan terkoordinasi dalam membuat bentuk gulungan kertas dengan lincah, yang mampu mengekspresikan diri melalui gerakan menggulung kertas secara detail, yang mampu dalam menempel gulungan kertas sesuai pola dan yang mampu dalam menempel gulungan kertas dengan rapi dan sesuai pola sehingga termasuk pada kategori Berkembang Sangat Baik (BSB).

Distribusi pengkategorian kemampuan motorik halus anak sesudah (post-test) diberikan kegiatan paper quilling.

Tabel 4.2 Kategori Kemampuan Motorik Halus Anak (Post-test)

\begin{tabular}{ccccc}
\hline No & Interval & Frekuensi & Kategori & Presentase \\
\hline 1 & $16-17$ & 0 & Belum Berkembang (BB) & $0 \%$ \\
\hline
\end{tabular}




\begin{tabular}{|c|c|c|c|c|}
\hline No & Interval & Frekuensi & Kategori & Presentase \\
\hline 2 & $18-19$ & 2 & Mulai Berkembang (MB) & $16,6 \%$ \\
\hline 3 & $20-21$ & 3 & Berkembang Sesuai Harapan (BSH) & $25 \%$ \\
\hline 4 & $22-23$ & 7 & Berkembang Sangat Baik (BSB) & $58,3 \%$ \\
\hline \multicolumn{2}{|c|}{ Jumlah } & 12 & - & $100 \%$ \\
\hline
\end{tabular}

Berdasarkan tabel diatas dapat diketahui bahwa dari 12 jumlah anak terdapat 0 anak dengan presentase $0 \%$ yang belum mampu dalam menggunakan tangan kanak dan kiri dalam menjepit kertas, belum mampu dalam menggunakan tangan kanan dan kiri dalam menggulung kertas, belum mampu melakukan gerakan terkoordinasi dalam membuat bentuk gulungan kertas dengan lincah, belum mampu mengekspresikan diri melalui gerakan menggulung kertas secara detail, belum mampu dalam menempel gulungan kertas sesuai pola dan belum mampu dalam menempel gulungan kertas dengan rapi dan sesuai pola sehingga termasuk pada kategori Belum Berkembang (BB).

Terdapat 2 anak dengan presentase 16,6\% yang mampu dalam menggunakan tangan kanak dan kiri dalam menjepit kertas, yang mampu dalam menggunakan tangan kanan dan kiri dalam menggulung kertas, yang mampu melakukan gerakan terkoordinasi dalam membuat bentuk gulungan kertas dengan lincah, yang mampu mengekspresikan diri melalui gerakan menggulung kertas secara detail, yang mampu dalam menempel gulungan kertas sesuai pola dan yang mampu dalam menempel gulungan kertas dengan rapi dan sesuai pola sehingga termasuk pada kategori Mulai Berkembang (MB).

Terdapat 3 anak dengan presentase $25 \%$ yang mampu dalam menggunakan tangan kanak dan kiri dalam menjepit kertas, yang mampu dalam menggunakan tangan kanan dan kiri dalam menggulung kertas, yang mampu melakukan gerakan terkoordinasi dalam membuat bentuk gulungan kertas dengan lincah, yang mampu mengekspresikan diri melalui gerakan menggulung kertas secara detail, yang mampu dalam menempel gulungan kertas sesuai pola dan yang mampu dalam menempel gulungan kertas dengan rapi dan sesuai pola sehingga termasuk pada kategori Berkembang Sesuai Harapan (BSH). Terdapat 7 anak dengan presentase 58,3\% yang mampu dalam menggunakan tangan kanak dan kiri dalam menjepit kertas, yang mampu dalam menggunakan tangan kanan dan kiri dalam menggulung kertas, yang mampu melakukan gerakan terkoordinasi dalam membuat bentuk gulungan kertas dengan lincah, yang mampu mengekspresikan diri melalui gerakan menggulung kertas secara detail, yang mampu dalam menempel gulungan kertas sesuai pola dan yang mampu dalam menempel gulungan kertas dengan rapi dan sesuai pola sehingga termasuk pada kategori Berkembang Sangat Baik (BSB).

Berdasarkan pemaparan di atas, dapat diketahui bahwa kemampuan motorik halus anak sebelum dan sesudah diberikan kegiatan paper quilling terdapat perubahan yang signifikan yaitu setelah diberikan kegiatan paper quilling terdapat 7 anak yang masuk dalam kategori Berkembang Sangat Baik (BSB), terdapat 3 anak yang masuk dalam kategori Berkembang Sesuai Harapan (BHS), terdapat 2 anak yang masuk dalam kategori Mulai Berkembang (MB), dan terdapat 0 anak yang masuk dalam kategori Belum Berkembang (BB). Data dari uji normalitas dengan menggunakan aplikasi SPSS data berdistribusi normal dapat dilihat di bahwa ini: 
30| TEMATIK, Juni 2021, Volume 7, Nomor 1, Halaman 24-32

Tabel 4.3 Uji Normalitas Kolmogorov Smirnov Pre-test dan Post-test

\begin{tabular}{|c|c|c|c|c|c|c|c|c|c|}
\hline \multicolumn{10}{|c|}{ Tests of Normality } \\
\hline \multirow{2}{*}{\multicolumn{2}{|c|}{$\begin{array}{l}\text { Usia 5-6 } \\
\text { Tahun }\end{array}$}} & \multicolumn{4}{|c|}{ Kolmogorov-Smirnov ${ }^{\mathrm{a}}$} & \multicolumn{4}{|c|}{ Shapiro-Wilk } \\
\hline & & \multicolumn{2}{|c|}{ Statistic } & $\mathrm{df}$ & Sig. & Statistic & $\mathrm{d}$ & & Sig. \\
\hline & re-test & \multicolumn{2}{|l|}{.167} & 12 & $.200^{*}$ & .944 & 12 & & .548 \\
\hline & ost-test & \multicolumn{2}{|l|}{.212} & 12 & .141 & .844 & 12 & & .031 \\
\hline \multicolumn{10}{|c|}{$\begin{array}{l}* \text { This is a lower bound of the true significance. } \\
\text { a. Lilliefors Significance Correction }\end{array}$} \\
\hline \multicolumn{10}{|c|}{$\begin{array}{l}\text { Dalam pengujian suatu data dikatakan berdistribusi normal apabila nilai signifikansi } \\
>0,05 \text {, dari perhitungan analisis data menunjukkan nilai signifikansi dari pre-test adalah } \\
0,200>0,05 \text { maka } \mathrm{H} 0 \text { diterima dan } \mathrm{H} 1 \text { ditolak maka data berdistribusi nomal. Nilai } \\
\text { signifikansi dari pre-test adalah } 0,141>0,05 \text { maka } \mathrm{H} 0 \text { diterima dan } \mathrm{H} 1 \text { ditolak maka data } \\
\text { berdistribusi nomal. Data dari Paired sampel tes dengan menggunakan aplikasi SPSS dapat } \\
\text { dilihat di bahwa ini: }\end{array}$} \\
\hline \multicolumn{10}{|c|}{ Tabel 4.4 Uji Paired Sampel Tes } \\
\hline \multicolumn{10}{|c|}{ Paired Samples Test } \\
\hline & & \multicolumn{5}{|c|}{ Paired Differences } & & & \\
\hline & & \multirow[t]{2}{*}{ Mean } & \multirow[t]{2}{*}{$\begin{array}{l}\text { Std. } \\
\text { Devi } \\
\text { ation }\end{array}$} & \multirow[t]{2}{*}{$\begin{array}{l}\text { Std. } \\
\text { Error } \\
\text { Mean }\end{array}$} & \multicolumn{2}{|c|}{$\begin{array}{l}\text { Confidence } \\
\text { Interval of the } \\
\text { Difference }\end{array}$} & & & \multirow[t]{2}{*}{$\begin{array}{l}\text { Sig. (2- } \\
\text { tailed) }\end{array}$} \\
\hline & & & & & Lower & Upper & & & \\
\hline Pair 1 & $\begin{array}{l}\text { Pretest - } \\
\text { Posttest }\end{array}$ & -2.500 & 1.087 & .314 & -3.191 & -1.809 & -7.966 & 11 & .000 \\
\hline
\end{tabular}

Berdasarkan hasil uji Paired sampel tes diperoleh nilai Sig. (2-tailed) 0,000 $<0,05$ maka dapat disimpulkan $\mathrm{HO}$ ditolak dan $\mathrm{H} 1$ diterima yang berarti terdapat pengaruh yang diberikan kegiatan paper quilling terhadap kemampuan motorik halus anak usia 5-6 tahu Taman Kanak-Kanak ABA II Arallae Kabupaten Bone. Pembahasan hasil penelitian yaitu dari hasil penelitian kemampuan motorik halus anak menunjukkan bahwa kegiatan paper quilling sangat efektif digunakan untuk membantu perkembangan motorik halus pada anak. Pernyataan tersebut diperkuat dengan berdasarkan hasil uji hipotesis yang menggunakan perhitungan uji statistik deskriptif, uji normalitas Kolmogorov Smirnov test, dan uji Paired sampel test yang hasilnya menunjukkan bahwa rata-rata hasil skor kemampuan motorik halus anak sesudah diberikan treatment kegiatan paper quilling terdapat peningkatan atau perubahan yang signifikan dibandingkan dengan kemampuan motorik halus anak sebelum diberikan perlakuan berupa kegiatan paper quilling. Dengan demikian dapat diketahui bahwa ada pengaruh dari kegiatan paper quilling terhadapa kemampuan motorik halus anak usia 5-6 tahun di Taman Kanak-Kanak ABA II Arallae. Penelitian ini sejalan dengan penelitian Khasanah (2013) bahwa keterampilan motorik halus anak dapat meningkat ketika anak melakukan kegiatan paper quilling. Hasil penelitian Khalimatussa'diah (2020) tentang pengaruh kegiatan paper quilling terhadap perkembangan motorik halus anak usia 
dini di Raudhatul Athfal Muslimat Totokarto Adiluwih Pringsewu menunjukkan bahwa terdapat pengaruh yang signifikan pada kemampuan motorik halus anak sesudah diberikan kegiatan paper quilling. Penelitian ini juga didukung oleh penelitian yang dilakukan oleh Damayanti (2015) menunjukkan bahwa kegiatan paper quilling dapat meningkatkan stabilitas gerak motorik halus anak. Hal ini menunjukkan bahwa melalui kegiatan paper quilling dapat membantu perkembangan kemampuan motorik halus anak.

\section{SIMPULAN}

Berdasarkan hasil penelitian dan pembahasan diatas, maka dapat disimpulkan bahwa kemampuan motorik halus anak usia 5-6 tahun mengalami perkembangan yang signifikan. Dalam pemberian kegiatan paper quilling terdapat peningkatan kemampuan anak sebelum dan sesudah diberikan kegiatan paper quilling. Disimpulkan bahwa ada perbedaan kemampuan motorik halus anak sebelum dan sesudah diberikan kegiatan paper quilling. Ini menandakan bahwa kegiatan paper quilling memiliki pengaruh terhadap kemampuan motorik halus pada anak usia 5-6 tahun di TK ABA II Arallae.

\section{DAFTAR PUSTAKA}

Ahmad Susanto, M. P. (2011). Perkembangan anak usia dini: pengantar dalam berbagai aspeknya. Kencana.

Artha, D. J., Sitompul, D. N., \& Hariani, P. P. (2020). Pelatihan Usaha Quilling Paper Bagi Guru Dalam Rangka Meningkatkan Sumber Daya Manusia Unggul Dan Kreatif. Jurnal Prodikmas Hasil Pengabdian Kepada Masyarakat, 5(1), 15-20.

Asmariani, Asmariania. 2016. "Konsep Media Pembelajaran Paud." Al-Afkar: Jurnal Keislaman \& Peradaban 5(1).

Bartkowski, Allison. 2011. “(12) Patent Application Publication (10) Pub. No: US 2011 / 0095126A1.”1(19).

Damayanti, N. (2015). Peningkatan Stabilitas Gerak Motorik Halus Anak Melalui Paper Quilling Pada Anak Kelompok B TK Aba Balong Cangkringan Sleman. Pendidikan Guru PAUD S-1.

Gaul, David, and Johann Issartel. 2016. "Human Movement Science Fine Motor Skill Proficiency in Typically Developing Children: On or off the Maturation Track?" Human Movement Science 46: 78-85. http://dx.doi.org/10.1016/j.humov.2015. 12.011.

Hera, Andi Junil, and Fadhilah Latief. 2020. "Peningkatan Kemampuan Motorik Halus Melalui Kegiatan Meronce Pada Anak Kelompok B Tk Islam Nurussalam Kabupaten Maros." TEMATIK: Jurnal Pemikiran dan Penelitian Pendidikan Anak Usia Dini 6(2): 99.

Huliyah, M. (2017). Hakikat Pendidikan Anak Usia Dini. As-Sibyan: Jurnal Pendidikan Anak Usia Dini, 1(01), 60-71.

Kamelia, N. (2019). Perkembangan Fisik Motorik Anak Usia Dini (Standar Tingkat Pencapaian Perkembangan Anak) Stppa Tercapai Di Ra Harapan Bangsa Maguwoharjo Condong Catur Yogyakarta. Kindergarten: Journal of Islamic Early Childhood Education, 2(2), 112-136. 
Khalimatussa'diah, K. D. (2020). Pengaruh Kegiatan Paper Quilling Terhadap Perkembangan Motorik Halus Anak Usia Dini Di Raudhatul Athfal Muslimat Totokarto Adiluwih Pringsewu (Doctoral dissertation, UIN Raden Intan Lampung).

Khasanah, I. (2013). Upaya Peningkatan Keterampilan Motorik Halus Melalui Paper Quilling Pada Anak Kelompok B4 Di TK Masyitoh Dukuh, Imogiri, Imogiri, Bantul. Skripsi Program Studi Pendidikan Anak Usia Dini Jurusan Pendidikan Pra Sekolah Dasar Fakultas Ilmu Pendidikan Universitas Negeri Yogyakarta.

Martzog, Philipp, and Sebastian Paul Suggate. 2019. "Journal of Experimental Child Fine Motor Skills and Mental Imagery: Is It All in the Mind?" Journal of Experimental Child Psychology 186: 59-72. https://doi.org/10.1016/j.jecp.2019.05.002.

Rahmawati, Septi, Oktaviani Ade Sapputri, and Zumrotul Affiyah. 2019. "Pemanfaatan Limbah Kertas Paper Quilling Sebagai Media Pembelajaran Biologi Melatih Daya Kreativitas Siswa." 3: 213-16.

Rohmatin, I. (2017). Peningkatan Motorik Halus Melalui Kegiatan Paper Quilling Pada Anak Kelompok B3 Di TK Darul Falah Cukir Diwek Jombang. PAUD Teratai, 6(3).

Suggate, Sebastian, Heidrun Stoeger, and Eva Pufke. 2016. "Relations between Playing Activities and Fine Motor Development." 4430(April): 0-14.

Suhartanti, Ika, Zulfa Rufaida, Widy Setyowati, and Fitria Wahyu Ariyanti. 2019. E-Book Penerbit STIKes Majapahit Stimulasi Kemampuan Motorik Halus Anak Pra Sekolah.

Suskin, Raymond. 2011. “(12) Patent Application Publication (10) Pub. No.: US 2011 / 0308696A1.” 1(19).

Wahyuningtyas, Dedek et al. 2020. "Penerapan Kegiatan 'Paper Quilling' Untuk Keterampilan Motorik Halus Anak Usia 5-6 Tahun.” 02: 9-16.

Wisudayanti, Ari, Kadek. 2017. Peningkatan Motorik Halus Anak Usia Dini Di Era Revolusi Industri 4.0. Jurnal Agama dan Budaya. 1 (2). 8-13. 